\title{
Profil pioderma pada orang dewasa di Poliklinik Kulit dan Kelamin RSUP Prof. Dr. R. D. Kandou Manado periode tahun 2013-2015
}

\author{
${ }^{1}$ Cindy E. Gama \\ ${ }^{2}$ Ferra O. Mawu \\ ${ }^{2}$ Renate T. Kandou \\ ${ }^{1}$ Kandidat Skripsi Fakultas Kedokteran Universitas Sam Ratulangi Manado, \\ ${ }^{2}$ Bagian/SMF Ilmu Kesehatan Kulit dan Kelamin Fakultas Kedokteran \\ Universitas Sam Ratulangi Manado \\ Email: cndgama@gmail.com
}

\begin{abstract}
Pyoderma is one of the most common skin infection caused mainly by Grampositive bacteria, Staphylococcus, Streptococcus, or both. It is closely associated with lowsosioeconomic, malnutrition, high density of population, and bad hygiene. This study was aimed to figure out the profile of pyoderma infection in adults at Department of Dermatovenereology, Prof. Dr. R. D. Kandou General Hospital Manado in the period of 2013-2015. This was a descriptive retrospective study using data of register books and medical records. The results showed that there were 164 new cases $(4.59 \%)$ of pyoderma in adults, predominantly males $(51,8 \%)$, age group of $45-64$ years $(44.5 \%)$, and folliculitis as the most clinical diagnosis. Most infections were treated with combination therapy of systemic antibiotic and topical antibiotic, clindamicyn (48.2\%) and fusidic acid (59.8\%) respectively.
\end{abstract}

Keywords: pyoderma, adult

\begin{abstract}
Abstrak: Pioderma merupakan salah satu penyakit infeksi kulit yang paling sering ditemui. Penyakit ini paling banyak disebabkan oleh kuman Gram-positif, yakni Staphylococcus dan Streptococcus, atau keduanya. Pioderma erat hubungannya dengan keadaan sosial ekonomi yang rendah, malnutrisi, kepadatan penduduk, dan sanitasi yang buruk. Penelitian ini bertujuan untuk mengetahui profil pioderma pada orang dewasa di Poliklinik Kulit dan Kelamin RSUP Prof. Dr. R. D. Kandou Manado periode tahun 2013-2015. Jenis penelitian ialah deskriptif retrospektif menggunakan data dari buku register dan catatan rekam medik. Hasil penelitian menunjukkan insidensi pioderma pada orang dewasa periode tahun 20132015 sebanyak 164 kasus baru (4,59\%). Distribusi terbanyak pada laki-laki (51,8\%), usia 4564 tahun (44,5\%), dengan bentuk klinis folikulitis $(38,4 \%)$. Sebanyak 95 pasien $(57,9 \%)$ menggunakan terapi kombinasi antibiotik sistemik dan antibiotik topikal. Terapi antibiotik sistemik yang terbanyak digunakan ialah klindamisin $(48,2 \%)$ dan antibiotik topikal yang paling banyak digunakan ialah asam fusidat $(59,8 \%)$.
\end{abstract}

Kata kunci: pioderma, dewasa

Pioderma merupakan salah satu penyakit infeksi kulit yang paling sering ditemui. ${ }^{1}$ Penyakit ini paling banyak disebabkan oleh kuman Gram-positif, yakni Staphylococcus dan Streptococcus atau keduanya serta dapat juga disebabkan oleh kuman Gram negatif misalnya Pseudomonas aeruginosa dan Proteus vulgaris. ${ }^{2}$ Pioderma erat hubungannya dengan keadaan sosial ekonomi yang rendah, malnutrisi, kepadatan penduduk, dan sanitasi yang buruk. $^{3}$

Pioderma diklasifikasikan menjadi dua yaitu, pioderma primer dan pioderma sekunder. ${ }^{2,4}$ Pioderma primer merupakan pioderma yang terjadi pada kulit yang 
sebelumnya sehat dan biasanya disebabkan oleh satu macam mikroorganisme sedangkan pioderma sekunder adalah pioderma yang terjadi pada kulit yang sakit atau telah ada penyakit kulit lain yang mendahului. ${ }^{2,4}$

Berdasarkan gambaran klinisnya pioderma terbagi menjadi pioderma superfisialis meliputi impetigo, ektima, folikulitis, furunkel, karbunkel, eritrasma, dan pioderma profunda meliputi erisipelas, selulitis, flegmon, dan lain sebagainya. ${ }^{2}$

Hasil penelitian oleh Ghandi ${ }^{1}$. di Department of Microbiology, Gajra Raja Medical College India tahun 2012, dari total 200 pasien dengan rentang usia 0-80 tahun, pioderma paling banyak ditemukan pada rentang usia 0-10 tahun sebanyak $48 \%, 21-30$ tahun sebanyak $21 \%$. Pioderma lebih banyak ditemukan pada laki-laki sebanyak $61,5 \%$, sedangkan jenis pioderma yang paling banyak ditemukan ialah impetigo sebanyak 53\% dan superfisial folikulitis sebanyak 39\%. ${ }^{1}$ Penelitian yang dilakukan oleh Fitri di poliklinik pagi (poli penyakit dalam dan poli anak) RS Karitas, Sumba Barat Daya pada bulan September 2014 mendapatkan insidensi pioderma sebanyak $17,9 \%$ dari total 78 pasien yang berkunjung. ${ }^{5}$ Hasil penelitian oleh Fahriah di RSUP Prof. Dr. R. D. Kandou Manado selama periode Januari hingga Desember 2012 mendapatkan pasien infeksi pioderma pada dewasa sebanyak $1,09 \%$ dari total 4023 kunjungan pasien. ${ }^{6}$

Sampai saat ini belum ada penelitian yang melaporkan tentang perkembangan penyakit pioderma pada orang dewasa di Kota Manado setelah tahun 2012. Evaluasi secara berkala harus terus dilaksanakan mengingat tingginya angka kejadian pioderma di Kota Manado Hal tersebut membuat peneliti tertarik untuk melakukan evaluasi terhadap perkembangan penyakit pioderma pada orang dewasa selama periode tahun 2013-2015 di RSUP Prof. Dr. R. D. Kandou Manado dihubungkan dengan usia, jenis kelamin, pekerjaan, dan terapi.

\section{METODE PENELITIAN}

Jenis penelitian ini ialah deskriptif retrospektif dengan menggunakan data yang diambil dari buku register dan catatan rekam medik pasien pioderma di Poliklinik Kulit dan Kelamin, disesuaikan dengan catatan rekam medik pasien di Instalasi Rekam Medik RSUP Prof. Dr. R. D. Kandou Manado. Populasi ialah semua pasien baru yang tercatat dengan penyakit kulit di Poliklinik Kulit dan Kelamin RSUP Prof. Dr. R. D. Kandou Manado mulai dari tahun 2013-2015. Sampel ialah semua pasien baru yang tercatat dengan diagnosis klinis pioderma usia $\geq 15$ tahun. Variabel penelitian yaitu usia, jenis kelamin, pekerjaan, bentuk klinis, dan terapi.

\section{HASIL PENELITIAN}

Penelitian secara retrospektif mengenai pioderma pada dewasa di Bagian Poliklinik Kulit dan Kelamin dan Instalasi Rekam Medik RSUP Prof. Dr. R. D. Kandou Manado periode tahun 2013 sampai dengan tahun 2015 mendapatkan pasien dewasa dengan infeksi pioderma sebanyak 164 kasus baru $(4,59 \%)$ dari total 3573 pasien penyakit kulit.

Pada Tabel 1 didapatkan jumlah kasus terbanyak pada tahun 2013 yaitu sebanyak 71 kasus $(4,87 \%)$ dari total 1457 pasien penyakit kulit, dan terendah pada tahun 2015 sebanyak 38 kasus $(4,30 \%)$ dari total 884 pasien penyakit kulit.

Tabel 1. Distribusi kunjungan pasien pioderma pada dewasa menurut jumlah penderita penyakit kulit pertahun.

\begin{tabular}{ccc}
\hline Tahun & $\begin{array}{c}\text { Jumlah pasien } \\
\text { penyakit kulit } \\
\text { (n) }\end{array}$ & $\begin{array}{c}\text { Jumlah pasien } \\
\text { pioderma (\%) }\end{array}$ \\
\hline 2013 & 1457 & $71(4,87 \%)$ \\
2014 & 1232 & $55(4,46 \%)$ \\
2015 & 884 & $38(4,30 \%)$ \\
Total & 3573 & $164(4,59 \%)$ \\
\hline
\end{tabular}

Berdasarkan jenis kelamin, pioderma lebih banyak ditemukan pada laki-laki yaitu sebanyak 85 kasus $(51,8 \%)$, sedangkan pada perempuan sebanyak 79 kasus (48,2\%) dengan ratio perbandingan 1,1:1 (Tabel 2). 
Tabel 2. Distribusi pasien pioderma pada dewasa menurut jenis kelamin

\begin{tabular}{ccc}
\hline Jenis kelamin & $\begin{array}{c}\text { Jumlah } \\
\text { pasien }(\mathbf{n})\end{array}$ & $\mathbf{( \% )}$ \\
\hline Laki-laki & 85 & 51,8 \\
Perempuan & 79 & 48,2 \\
Total & 164 & 100 \\
\hline
\end{tabular}

Distribusi pasien pioderma terbanyak yaitu pada kelompok usia 45-64 tahun sebanyak 73 kasus $(44,5 \%)$ (Tabel 3).

Tabel 3. Distribusi pasien pioderma pada dewasa menurut usia

\begin{tabular}{ccc}
\hline Usia & $\begin{array}{c}\text { Jumlah pasien } \\
(\mathbf{n})\end{array}$ & \% \\
\hline $15-24$ & 28 & 17,1 \\
$25-44$ & 40 & 24,4 \\
$45-64$ & 73 & 44,5 \\
$\geq 65$ & 23 & 14 \\
Total & 164 & 100 \\
\hline
\end{tabular}

Bentuk klinis pioderma terbanyak ialah folikulitis sebanyak 63 kasus $(38,4 \%)$.

Tabel 4. Distribusi bentuk klinis pioderma pada dewasa

\begin{tabular}{lcc}
\hline $\begin{array}{c}\text { Bentuk klinis } \\
\text { pioderma }\end{array}$ & $\begin{array}{c}\text { Jumlah } \\
\text { pasien (n) }\end{array}$ & \% \\
\hline Impetigo Krustosa & 3 & 1,8 \\
Impetigo bulosa & 1 & 0,6 \\
Folikulitis & 63 & 38,4 \\
Furunkel & 39 & 23,8 \\
Karbunkel & 6 & 3,7 \\
Ektima & 5 & 3,0 \\
Erisipelas & 13 & 7,9 \\
Selulitis & 32 & 19,5 \\
Hidradenitis Supurativa & 2 & 1,2 \\
Total & 164 & 100 \\
\hline
\end{tabular}

Tabel 5. Distribusi terapi pada pasien pioderma dewasa

\begin{tabular}{lcc}
\hline \multicolumn{1}{c}{ Terapi } & $\begin{array}{c}\text { Jumlah } \\
\text { pasien (n) }\end{array}$ & \% \\
\hline Antibiotik & 95 & 57,9 \\
sistemik+topikal & & \\
Antibiotik Sistemik & 36 & 22,0 \\
Antibiotik Topikal & 33 & 20,1 \\
Total & 164 & 100 \\
\hline
\end{tabular}

Terapi kombinasi diberikan pada 95 pasien (57,9\%) (Tabel 5). Antibiotik sistemik yang paling banyak digunakan ialah klindamisin sebanyak 79 pasien (48,2\%) (Tabel 6). Antibiotik topikal yang paling banyak digunakan ialah asam fusidat sebanyak 98 pasien $(59,8 \%)$ (Tabel 7).

Tabel 6. Distribusi penggunaan antibiotik sistemik

\begin{tabular}{lcc}
\hline \multicolumn{1}{c}{ Antibiotik } & $\begin{array}{c}\text { Jumlah } \\
\text { pasien (n) }\end{array}$ & \% \\
\hline Sefadroksil & 40 & 24,4 \\
Doksisiklin & 3 & 1,8 \\
Klindamisin & 79 & 48,2 \\
Amoksisilin & 3 & 1,8 \\
Eritromisin & 4 & 2,4 \\
Ciprofloksasin & 1 & 0,6 \\
Co-Amoksiklav & 1 & 0,6 \\
Tidak menggunakan & 33 & 20,1 \\
antibiotik sistemik & & \\
Total & 164 & 100 \\
\hline
\end{tabular}

Tabel 7. Distribusi penggunaan antibiotik topikal

\begin{tabular}{lcc}
\hline \multicolumn{1}{c}{ Antibiotik } & $\begin{array}{c}\text { Jumlah } \\
\text { pasien (n) }\end{array}$ & \% \\
\hline Asam fusidat & 98 & 59,8 \\
Mupirosin & 12 & 7,3 \\
Gentamisin & 12 & 7,3 \\
Silver sulfadiazine & 4 & 2,4 \\
Eritromisin & 1 & 0,6 \\
Neomisin & 1 & 0,6 \\
Tidak menggunakan & 36 & 22,0 \\
antibiotik topikal & 164 & 100 \\
Total & & \\
\hline
\end{tabular}

\section{BAHASAN}

Pada penelitian ini, sampel yang diambil adalah seluruh pasien kasus baru dengan diagnosa klinis pioderma, usia $\geq 15$ tahun yang berkunjung di Poliklinik Kulit dan Kelamin RSUP Prof. Dr. R. D. Kandou Manado mulai dari tahun 2013 sampai dengan tahun 2015.

Berdasarkan distribusi kunjungan kasus pertahun di Poliklinik Kulit dan Kelamin RSUP Prof. Dr. R. D. Kandou Manado pada tahun 2013 dari total 1457 pasien penyakit kulit, sebanyak 71 pasien $(4,87 \%)$ didiagnosis sebagai pioderma. Pada penelitian yang dilakukan oleh 
Fahriah $^{6}$ di Poliklinik Kulit dan Kelamin RSUP Prof. Dr. R. D. Kandou Manado periode Januari hingga Desember 2012 dari total 4023 kunjungan, pioderma didiagnosis pada 44 pasien $(1,09 \%)$. Hal tersebut menunjukkan pada tahun 2013 insidensi pioderma meningkat dari tahun sebelumnya.

Pada tahun 2014 dan tahun 2015 insidensi pioderma mengalami penurunan; hal ini mungkin disebabkan karena pada tahun 2014 Badan Penyelenggara Jaminan Sosial Kesehatan (BPJS kesehatan) mulai diberlakukan. BPJS sendiri membuat aturan dimana pioderma termasuk di dalam 155 penyakit yang wajib ditangani oleh fasilitas kesehatan tingkat pertama. ${ }^{7}$

Data distribusi menurut jenis kelamin memperlihatkan pioderma ditemukan lebih banyak pada laki-laki $(51,8 \%)$ dibandingkan perempuan $(48,2 \%)$, namun tidak menunjukkan perbedaan yang mencolok dengan ratio perbandingan $1,1: 1$. Hal ini selaras dengan penelitian yang dilakukan oleh Ghandi et al. ${ }^{1}$ di Department of Microbiology, Gajra Raja Medical College India tahun 2012 dimana pioderma lebih banyak ditemukan pada laki-laki $(61,2 \%)$ dibandingkan perempuan $(38,5 \%) .{ }^{1} \mathrm{Hal}$ ini berbanding terbalik dengan penelitian yang dilakukan oleh Fahriah di Poliklinik Kulit dan Kelamin RSUP Prof. Dr. R. D. Kandou Manado periode Januari hingga Desember 2012, yang mendapatkan pioderma lebih banyak pada perempuan $(52,3 \%)$ daripada laki-laki $(47,7 \%){ }^{6}$

Dalam penelitian ini tidak ditemukan perbedaan mencolok antara laki-laki dan perempuan. Tidak ada alasan spesifik mengenai insidensi pioderma yang lebih tinggi pada laki-laki; hal ini mungkin karena laki-laki lebih sering beraktivitas di luar rumah sehingga meningkatkan resiko terjadinya trauma. ${ }^{8}$ Pada perempuan juga trauma bisa terjadi karena kebiasaan mencukur rambut ketiak, penggunaan make-up dan kebiasaan menggunakan pakaian ketat berbahan kasar. ${ }^{9}$

Data distribusi menurut usia menunjukkan pioderma paling banyak ditemukan pada kelompok usia 45-64 tahun
$(44,5 \%)$ dan paling sedikit ditemukan pada kelompok usia $\geq 65$ tahun $(14,0 \%)$. Penelitian yang dilakukan oleh Fahriah ${ }^{6}$ di Poliklinik Kulit dan Kelamin RSUP Prof. Dr. R. D. Kandou Manado periode Januari hingga Desember 2012 juga menunjukkan pioderma paling banyak ditemukan pada kelompok usia 45-64 tahun yaitu sekitar $52,3 \%$.

Banyaknya pasien pioderma pada kelompok usia 45-64 tahun kemungkinan berhubungan dengan perubahan fisiologis yang terjadi karena proses penuaan dimana terdapat perubahan fisiologis kulit berupa atrofi pada lapisan epidermis dan dermis, berkurangnya kemampuan kulit untuk melindungi diri dari trauma fisik dan penyembuhan luka berkepanjangan serta berhubungan erat dengan kondisi fisik dan status imunitas seluler yang mendasari sehingga mempermudah terjadinya infeksi antara lain penyakit sistemik kronis seperti diabetes melitus, keadaan imunokompromais (keganasan, radiasi, kemoterapi, terapi steroid sistemik), menurunnya kewaspadaan terhadap trauma kulit (luka tusuk kecil dan dalam), riwayat operasi, sumbatan limfatik, dan rendahnya kesadaran menjaga kebersihan. ${ }^{10}$

Data distribusi menurut bentuk klinis pioderma menunjukkan folikulitis merupakan bentuk klinis yang paling banyak ditemukan yaitu sebanyak $38,4 \%$, diikuti oleh furunkel sebanyak $23,8 \%$. Penelitian yang dilakukan oleh Fahriah ${ }^{6}$ di Poliklinik Kulit dan Kelamin RSUP Prof. Dr. R. D. Kandou Manado periode Januari hingga Desember 2012 menunjukkan hal yang sedikit berbeda yaitu bentuk klinis pioderma yang paling banyak ditemukan yaitu selulitis sebanyak 52,3\%. Penelitian lain yang dilakukan oleh Bhat et al. ${ }^{11}$ di Department of Dermatology, Sexually Transmitted Diseases and Leprosy of Shri Maharaja Hari Singh Hospital, Srinagar, Jammu and Kashmir, India tahun 2013 menunjukkan furunkel merupakan bentuk klinis pioderma yang paling banyak ditemukan yaitu sebanyak $51 \%$.

Folikulitis, furunkel dan karbunkel adalah radang pada folikel rambut dan 
jaringan disekitarnya, paling sering disebabkan oleh kuman Gram-positif yaitu Staphylococcus aureus. Staphylococcus aureus merupakan salah satu kuman penyebab yang paling sering menyebabkan infeksi kulit dan infeksi sistemik. Pada penelitian ini, folikulitis dan furunkel merupakan bentuk klinis pioderma pada dewasa yang paling banyak ditemukan; hal ini mungkin dikarenakan pada orang dewasa lebih mudah terjadi trauma pada folikel rambut. Trauma itu sendiri mungkin didapatkan dari kebiasaan mencukur, menggunakan pakaian ketat dan berbahan kasar yang dapat menyebabkan iritasi pada kulit, sumbatan pada folikel rambut misalnya oleh keringat, sebum, dan makeup, dan dapat juga dihubungkan dengan diabetes melitus dan infeksi HIV. ${ }^{9}$

Pada Tabel 6 dapat dilihat data mengenai distribusi terapi pioderma. Dari hasil tersebut dapat disimpulkan bahwa terapi kombinasi antara antibiotik sistemik dan antibiotik topikal merupakan terapi yang paling sering diberikan $(57,9 \%)$, diikuti pemberian antibiotik sistemik $(22,0 \%)$ dan antibiotik topikal $(20,1 \%)$. Pemberian terapi kombinasi mungkin lebih efektif daripada hanya diberikan monoterapi.

Distribusi penggunaan antibiotik sistemik yang paling banyak digunakan ialah klindamisin sebanyak 48,2\%. Penelitian yang dilakukan oleh Fahriah ${ }^{6}$ di Poliklinik Kulit dan Kelamin RSUP Prof. Dr. R. D. Kandou Manado periode Januari hingga Desember 2012 juga menunjukkan bahwa antibiotik sistemik yang paling banyak digunakan ialah klindamisin sebanyak $65,9 \%$.

Infectious Diseases Society of America (IDSA) membuat Practice Guidelines for the Diagnosis and Management of Skin and Soft Tissue Infections tahun 2014, dimana terapi antibiotik sistemik yang dianjurkan untuk impetigo dan ektima ialah penisilin atau sefalosporin generasi pertama misalnya sefadroksil, dan untuk pasien yang alergi terhadap penisilin, terapi yang dianjurkan ialah doksisiklin, klindamisin dan eritromisin, sedangkan pada folikulitis, furunkel, dan karbunkel antibiotik sistemik yang dianjurkan ialah antibiotik yang efektif terhadap infeksi kuman Staphylococcus aureus salah satunya ialah klindamisin, serta pada selulitis dan erisipelas antibiotik sistemik yang dianjurkan ialah antibiotik yang efektif terhadap infeksi kuman Streptococcus seperti penisilin, amoksisilin, amoksisilinklavulanat, atau klindamisin. ${ }^{12}$

Distribusi penggunaan antibiotik topikal yang paling banyak digunakan ialah asam fusidat sebanyak 59,8\%. Penelitian yang dilakukan oleh Fahriah ${ }^{6}$ di Poliklinik Kulit dan Kelamin RSUP Prof. Dr. R. D. Kandou Manado periode Januari hingga Desember 2012 di Poliklinik Kulit dan Kelamin RSUP Prof. Dr. R. D. Kandou Manado tahun 2012 antibiotik topikal yang paling banyak digunakan adalah asam fusidat $31,8 \%$. Pada penelitian ini asam fusidat ialah antibiotik topikal yang paling banyak digunakan; hal ini mungkin dikarenakan rata-rata pasien yang datang di Poliklinik Kulit dan Kelamin RSUP Prof. Dr. R. D. Kandou Manado menggunakan jaminan kesehatan BPJS, dimana asam fusidat masuk dalam daftar obat yang ditanggung oleh BPJS kesehatan. ${ }^{13}$

Terapi antibiotik topikal yang dianjurkan oleh Infectious Diseases Society of America (IDSA) tahun 2014 untuk impetigo, ektima, folikulitis, furunkel, dan karbunkel ialah mupirosin. Hal ini berbeda dengan hasil penelitian yang penulis lakukan dimana asam fusidat lebih banyak digunakan daripada mupirosin hal ini dikarenakan sediaan asam fusidat tidak tersedia di Amerika Serikat sehingga mupirosin menjadi antibiotik topikal yang dianjurkan oleh IDSA. ${ }^{12,14}$

\section{SIMPULAN}

Dari hasil penelitian tentang pioderma pada orang dewasa di poliklinik kulit dan kelamin RSUP Prof. Dr. R. D. Kandou Manado periode tahun 2013 sampai tahun 2015 dapat disimpulkan insidensi pioderma pada orang dewasa sebesar $4,59 \%$. Distribusi pioderma terbanyak pada jenis kelamin laki-laki, usia 45-64 tahun, dengan 
bentuk klinis folikulitis. Terapi yang paling sering diberikan ialah terapi kombinasi antibiotik sistemik dan antibiotik topikal. Antibiotik sistemik terbanyak yang digunakan ialah klindamisin dan antibiotik topikal yang paling banyak digunakan ialah asam fusidat.

\section{SARAN}

1. Kelengkapan dalam pengisian status pasien sangat diperlukan guna menunjang pendataan yang lengkap, akurat dan informatif.

2. Perlu dilakukan penelitian lebih lanjut mengenai hubungan pekerjaan dan insidensi terjadinya pioderma.

3. Perlu dilakukan evaluasi secara berkala untuk melihat perkembangan penyakit pioderma mengingat masih tingginya angka insidensi pioderma khususnya di kota Manado.

\section{DAFTAR PUSTAKA}

1. Gandhi S, Ojha A K, Ranjan $K$, Neelima. Clinical and bacteriological aspects of pyoderma. North American Journal of Medical Sciences 2012;4:492-495.

2. Hsu JTS. Manual of Dermatologic Therapeutics (7th ed).. Arndt KA, editor. Philadelphia: Lippincott Williams \& Wilkins, 2007; p. 31-41.

3. Sutisna IA, Harlisa P, Zulaikhah ST. Hubungan antara hygiene perorangan dan lingkungan dengan kejadian pioderma. Sains Medica Journal of Medicine. 2011;3(1):25-30.

4. Menaldi Sri Linuwih SW, editor. Ilmu Penyakit Kulit dan Kelamin (7th ed). Jakarta:. Badan penerbit Fakultas Kedokteran Universitas Indonesia, 2015; p. 3-4.

5. Azizah F. Frekuensi penyakit kulit di RS Karitas, Sumba Barat Daya September 2014. eJurnal Fakultas Kedokteran Universitas Indonesia. 2014;2(3):148-150.

6. Fahriah. Profil pioderma pada dewasa di poliklinik kulit dan kelamin RSUP
Prof. Dr. R. D. Kandou Manado periode Januari-Desember 2012 [Skripsi]. Manado: Fakultas Kedokteran Unsrat; 2014.

7. Daftar penyakit yang ditanggung BPJS kesehatan. [cited 11 November 2016]. Available from: http://www.bpjskis.info/2015/09/daftar-penyakityang-ditanggung-bpjs.html

8. Venkatesh BMS, Nagaraju K, Vivekananda N. Bacteriological profile and antibiotic susceptibility of pyodermas at a tribal tertiary care Hospital. Sch J App Med Sci. 2016; 4(8E):3087-91.

9. Hall JC. Dermatologic bacteriology. In: Hall BJ, Hall JC, penyunting. Sauer's Manual of Skin Diseases (10th ed). Philadelphia: Lippincott Williams and Wilkins, 2010; p. 202-19.

10.Marcet S, Ali A, Farnsworth N. Chapter 18 Bacterial diseases. In: Ali A, penyunting. McGraw-Hill Specialty Board Review Dermatology A Pictorial Review (3rd ed). McGrawHill education. 2015:321-3.

11.Bhat YJ, Hassan, Bashir S, Farhana A, Maroof P. Clinico-bacteriological profile of primary pyodermas in Kashmir: a hospital-based study. JR Coll Physicians Edinb. 2016;46:8-13.

12.Stevens DL, Bisno AL, Chambers HF, Dellinger EP, Goldstein EJC, Gorbach SL, et al. Practice guidelines for the diagnosis and management of skin and soft tissue infections: 2014 update by the Infectious Diseases Society of America. Clinical Infectious Diseases Advance Access. 2014:1-36.

13. Keputusan Menteri Kesehatan RI Nomor HK.02.02/Menkes/523/2015 tentang Formularium Nasional. [cited 24 November 2016]. Available from:http://infobpjs.net/keputusanmenteri-kesehatan-ri-nomor-hk-0202menkes5232015-tentangformularium-nasional/

14.Pereira LB. Impetigo - review. An Bras Dermatol. 2014;89(2):293-9. 